\title{
PENERAPAN PP 46 TAHUN 2013: ADILKAH PERATURAN INI BAGI PELAKU USAHA MIKRO KECIL DAN MENENGAH (UMKM)?
}

\author{
Dianila Oktyawati ${ }^{1}$, Faridiah Aghadiati Fajri ${ }^{2}$ \\ ${ }_{1,2}$ Program Studi Akuntansi/Departemen Ekonomika dan Bisnis/Sekolah Vokasi, Universitas Gadjah Mada, Indonesia \\ Email: 'dianila.oktyawati@ugm.ac.id \\ Email: ${ }^{2}$ faridiahagha@ugm.ac.id
}

\begin{abstract}
ABSTRAK
Pajak adalah sumber pendapatan negara terbesar. Hal ini ditunjukkan dalam Anggaran Pendapatan dan Belanja Negara (APBN) tahun 2017 bahwa target penerimaan negara dari sektor pajak adalah 85,6\%. Di Indonesia, UMKM merupakan usaha yang paling berkembang dalam segi jumlahnya. Keberadaan UMKM memainkan peran penting dalam pembangunan ekonomi rakyat di suatu negara dan memiliki potensi untuk meningkatkan kesejahteraan masyarakat. Salah satu upaya pemerintah untuk meningkatkan penerimaan pajak dari sektor UMKM adalah penegakan Peraturan Pemerintah No. 46 tahun 2013. PP 46/2013 tentang pajak penghasilan atas penghasilan dari bisnis yang diterima atau diperoleh oleh pembayar pajak yang memiliki pendapatan bruto tertentu yaitu pendapatan bruto kurang dari $R p$ 4,8 miliar, - dalam satu tahun. Penelitian ini bertujuan untuk menguji keadilan dalam penerapan PP 46 pada UMKM. Analisis yang digunakan adalah analisis deskriptif kualitatif. Hasil penelitian ini menunjukkan bahwa penerapan PP No. 46 adalah sederhana, mudah diterapkan untuk UMKM. Tetapi PP ini dirasa tidak adil. Hal ini dikarenakan PP ini hanya menguntungkan kelompok UMKM yang memiliki margin laba di atas $8 \%$ dari pendapatan bruto, sebaliknya jika margin laba di bawah 8\% akan merugikan UMKM. Ini disebabkan dalam perhitungan PP 46 dihitung dari pendapatan bruto, bukan laba, artinya jika perusahaan mendapat sedikit untung atau bahkan menderita kerugian akan tetap dikenai pajak. Selain itu, PP ini juga tidak memperhatikan jumlah tanggungan (PTKP) dalam menghitung pajak untuk pelaku UMKM wajib pajak orang pribadi.
\end{abstract}

Kata Kunci: keadilan, PP No 46 Tahun 2013, UMKM.

\section{PENDAHULUAN}

Pajak merupakan sumber penerimaan negara terbesar. Hal ini ditunjukkan dalam Anggaran Penerimaan dan Belanja Negara (APBN) tahun 2017 bahwa target penerimaan negara dari sektor perpajakan adalah sebesar $85,6 \%$. Demikian pula, dalam data APBN tahun 2018 penerimaan negara dari sektor perpajakan ditargetkan sebesar 85,4\% (Kementrian Keuangan, 2018). Hal ini sesuai yang diungkapkan oleh Mardiasmo (2016) bahwa salah satu fungsi pajak adalah untuk anggaran (budgetair), yakni pajak digunakan untuk membiayai pengeluaran-pengeluaran negara. Hal ini dikarenakan dalam menjalankan pemerintahan dan membiayai pembangunan infrastruktur, negara tentu akan membutuhkan biaya dalam jumlah yang tidak sedikit. Oleh karena itu, berbagai kebijakan dilakukan oleh pemerintah demi tercapainya target penerimaan dari sektor perpajakan.

Salah satunya adalah dengan diberlakukannya Peraturan Pemerintah No 46 tahun 2013 tentang pajak penghasilan atas penghasilan dari usaha yang diterima atau diperoleh wajib pajak yang memiliki peredaran bruto tertentu. Peredaran bruto yang dimaksud adalah peredaran bruto kurang dari Rp 4.800.000.000,- dalam satu tahun. Ini menandakan sasaran dari PP ini adalah pelaku Usaha Mikro Kecil dan Menengah (UMKM).

Di Indonesia, UMKM merupakan usaha yang paling berkembang dari segi jumlahnya. UMKM memainkan peranan penting dalam perkembangan ekonomi rakyat pada suatu negara dan berpotensi meningkatkan kesejahteraan rakyat. Dengan potensi yang demikian, disinyalir bahwa keberadaan UMKM juga dapat meningkatkan pendapatan pajak bagi negara. Oleh karena itu, muncullah PP No 46 tahun 2013 ini karena selama belum adanya PP tersebut, UMKM masih luput dari pengenaan pajak.

Luputnya pengenaan pajak dari sektor UMKM disebabkan karena belum adanya aturan yang mengatur tentang perpajakan pada sektor ini dan rumitnya perhitungan perpajakan. Dengan demikian, muncullah PP 46 ini sebagai jawaban atas permasalahan tersebut yakni memberi kemudahan bagi wajib yang memiliki 
peredaran kurang dari yang dipersyaratkan tersebut. Pasalnya dalam hal ini pengenaan tarifnya adalah sebesar $1 \%$ dikalikan dengan omset.

Omset adalah penghasilan bruto atau penghasilan kotor sebelum dikurangi dengan harga pokok produksi dan biaya-biaya lainnya. Dengan kata lain, omset berbeda halnya dengan laba. Dengan demikian, dapat dikatakan bahwa PP ini tidak memandang berapa laba yang diterima wajib pajak, bahkan apakah wajib pajak sedang mengalami laba atau rugi. Sekilas PP ini Nampak tidak adil bagi pelaku UMKM meskipun di sisi lain PP ini sangat mudah diterapkan karena pengenaan tarifnya ahnya $1 \%$ dikalikan dengan omsetnya. Oleh karena itu, studi ini akan membahas mengenai Penerapan PP 46 No 46 Tahun 2013 bagi Pelaku UMKM.

\section{TINJAUAN PUSTAKA}

\section{Usaha Kecil Mikro Menengah (UMKM)}

UMKM merupakan singkatan dari Usaha Mikro, Kecil, dan Menengah. Menurut UU No. 20 tahun 2008, usaha mikro merupakan usaha produktif milik perorangan dan/atau badan usaha perorangan yang memenuhi kriteria aset kurang dari sama dengan $\mathrm{Rp} 50.000 .000$,dan omzet kurang dari sama dengan Rp 300.000,-. Sedangkan usaha kecil merupakan usaha ekonomi produktif yang berdiri sendiri yang dilakukan oleh orang perorangan/ badan usaha yang bukan merupakan anak perusahaan/ bukan cabang perusahaan yang dimiliki, dikuasai, atau menjadi bagian baik langsung dari usaha menengah atau usaha besar yang memenuhi kriteria asenya lebih dari Rp 50.000.000,- sampai dengan Rp 500.000.000,- dan omzetnya melebihi Rp 300.000.000,sampai dengan Rp 2.500.000.000,-. Selanjutnya, usaha menengah merupakan usaha produktif yang berdiri sendiri yang dilakukan oleh perseorangan atau badan usaha yang bukan merupakan anak perusahaan atau cabang perusahaan yang dimiliki, dikuasai, atau menjadi bagian baik langsung maupun tidak langsung dengan usaha kecil atau usaha besar yang memenuhi kriteria asetnya lebih dari Rp 500.000.000,- sampai dengan Rp 2.500.000.000,- dan omzetnya lebih dari Rp 2.500.000.000 sampai dengan Rp 50.000.000.000,. Undang-undang No 20 tahun 2008 menjelaskan bahwa kriteria UMKM nilai nominalnya dapat diubah sesuai dengan perkembangan perekonomian yang diatur oleh Peraturan Presiden. Kriteria tersebut dapat dirangkum dalam tabel di bawah ini.
Tabel 1. Karakteristik Usaha Mikro Kecil Menengah (UMKM)

\begin{tabular}{clccc}
\hline No & Kriteria & $\begin{array}{c}\text { Usaha } \\
\text { Mikro }\end{array}$ & Usaha Kecil & $\begin{array}{c}\text { Usaha } \\
\text { Menengah }\end{array}$ \\
\hline 1 & Aset & $<50$ jt & $>50-500$ jt & $>500$ jt-10M \\
2 & Omzet & $<300$ jt & $>300$ jt-2,5M & $>2,5 \mathrm{M}-50 \mathrm{M}$ \\
3 & Pegawai & $1-9$ orang & $10-19$ orang & $20-99$ orang \\
\hline
\end{tabular}

Sumber: UU No 20 tahun 2008

\section{Definisi dan Fungsi Pajak}

Menurut UU No 16 Tahun 2009 tentang perubahan keempat atas UU No 6 Tahun 1983, pajak merupakan kontribusi wajib kepada negara yang terutang oleh orang pribadi atau badan yang bersifat memaksa berdasarkan Undang-Undang, dengan tidak mendapatkan imbalan secara langsung dan digunakan untuk keperluan negara bagi sebesar-besarnya kemakmuran rakyat.

Mardiasmo (2016) mengungkapkan fungsi pajak adalah sebagai berikut.

a. Fungsi anggaran (budgetair)

Pajak berfungsi sebagai salah satu sumber dana bagi pemerintah untuk membiayai pengeluaranpengeluarannya.

b. Fungsi mengatur (regulerend)

Pajak berfungsi sebagai alat untuk mengatur atau melaksanakan kebijaksanaan pemerintah dalam bidang sosial dan ekonomi.

\section{Asas-asas Pemungutan Pajak}

Menurut Adam Smith dalam Waluyo (2013), pemungutan pajak sebaiknya didasarkan pada asasasas berikut ini.

a. Keadilan (Equality)

Pemungutan pajak harus bersifat adil dan merata yakni pajak dikenakan kepada wajib pajak disesuaikan dengan kemampuan masing-masing.

b. Kepastian (certainty)

Penetapan pajak itu tidak ditentukan sewenangwenang. Oleh karena itu, Wajib Pajak harus mengetahui secara jelas dan pasti besarnya pajak yang terutang, kapan harus dibayar, serta batas waktu pembayaran.

c. Kenyamanan (convenience)

Pembayaran pajak hendaknya memperhatikan waktu yang tidak menyulitkan wajib pajak untuk membayar. Misalnya, pada saat Wajib Pajak memperoleh penghasilan. 


\section{d. Ekonomis (economy)}

Secara ekonomi bahwa biaya pemungutan dan biaya pemenuhan kewajiban Wajib Pajak diharapkan seminimum mungkin, demikian juga beban yang ditanggung Wajib Pajak.

Sedangkan, Mardiasmo (2016) menjelaskan bahwa syarat pemungutan pajak adalah sebagai berikut.

a. Syarat Keadilan, yakni pemungutan pajak harus adil disesuaikan dengan kemampuan masingmasing.

b. Syarat Yuridis, yakni pemungutan pajak diatur dalam UUD 1945 pasal 23 yang memberikan jaminan hukum untuk menyatakan keadilan, baik bagi negara maupun warganya.

c. Syarat Ekonomis, yakni pemungutan tidak boleh menganggu kelancaran kegiatan produksi maupun perdagangan sehingga tidak menimbulkan kelesuan perekonomian masyarakat.

d. Syarat Finansial, yakni biaya pemungutan pajak harus lebih rendah dari hasil pemungutannya.

e. Sederhana, yakni sistem pemungutan pajak yang sederhana akan memudahkan dan mendorong masyarakat dalam memnuhi kewajiban perpajakannya.

\section{Peraturan Pemerintah No 46 Tahun 2013}

Peraturan Pemerintah No 46 tahun 2013 (PP no 46 tahun 2013) mulai diberlakukan pada tanggal 1 Juli 2013. PP ini mengatur tentang pajak penghasilan tas penghasilan dari usaha yang diterima atau diperoleh wajib pajak (WP) yang memiliki peredaran bruto tertentu. Dalam hal ini, yang dimaksud WP yang memiliki peredaran bruto tertentu adalah WP orang pribadi (WPOP) atau WP badan yang tidak termasuk bentuk usaha tetap dan menerima penghasilan dari usaha tidak termasuk penghasilan dari jasa sehubungan dengan pekerjaan bebas dengan peredaran bruto tidak melebihi Rp4.800.000.000,00 (empat miliar delapan ratus juta rupiah) dalam 1 (satu) tahun pajak.

Namun ada beberapa WP yang dikecualikan dari PP ini yaitu WPOP yang melakukan usaha perdagangan dan/atau jasa yang dalam usahanya menggunakan sarana atau prasarana yang dapat dibongkar pasang, baik yang menetap maupun yang tidak menetap dan menggunakan sebagian atau seluruh tempat untuk kepentingan umum yang tidak diperuntukkan bagi tempat usaha atau berjualan. Selain itu, terdapat pula perkecualian bagi WP badan yakni WP badan yang belum beroperasi secara komersial atau WP badan yang dalam jangka waktu 1 (satu) tahun setelah beroperasi secara komersial memperoleh peredaran bruto melebihi Rp4.800.000.000,00.

PP ini menetapkan pajak penghasilan bersifat final dalam pengenaannya, yakni $1 \%$ (satu persen). Pajak penghasilan bersifat final adalah pajak penghasilan yang pengenaannya sudah final sehingga tidak dapat dikurangkan atau dikreditkan dari total pajak penghasilan terutang pada akhir tahun pajak (Resmi, 2017). Tarif 1\% tersebut dikalikan dengan peredaran bruto dari usaha dalam waktu 1 tahun.

Menurut PP 46 tahun 2013 pasal 3 ayat 3 menyatakan bahwa apabila dalam hal peredaran bruto kumulatif WP pada suatu bulan telah melebihi jumlah Rp4.800.000.000,- dalam suatu tahun pajak, WP tetap dikenai tarif pajak $1 \%$ sampai pada akhir tahun pajak.

Sedangkan apabila dalam hal peredaran bruto WP telah melebihi jumlah Rp4.800.000.000,0 pada suatu tahun pajak, atas penghasilan diterima atau diperoleh WP pada tahun pajak berikutnya dikenai tarif PPh berdasarkan ketentuan UU PPh.

Pasal 4 PP 46 tahun 2013 menegaskan bahwa dasar pengenaan pajak untuk menghitung $\mathrm{PPh}$ yang bersifat final adalah jumlah peredaran bruto setiap bulan. Oleh karena itu, dapat diringkas perhitungannya adalah $1 \%$ dikalikan dengan peredaran bruto per bulan.

\section{Sebelum diberlakukan PP 46 Tahun 2013}

Sebelum adanya peraturan PP 46 tahun 2013, Wajib Pajak yang dengan peredaran bruto kurang dari Rp4.800.000.000,- dalam tahun pajak menggunakan Pajak Penghasilan Pasal 31E dengan tarif 12,5\% dari laba sebelum pajak.

Dalam UU no 36 Tahun 2008 pasal 31 E dijelaskan bahwa pelaku usaha yang berbentuk badan yang berpenghasilan tidak lebih dari Rp 4,8 miliar dalam satu tahun pajak akan memperoleh penurunan tarif 50\% dari tarif umum UU PPh sebesar 25\% yang dihitung dari laba bersih sebelum pajak yang telah dikurangi dengan biaya-biaya yang diperkenankan dalam peraturan perpajakan. Sedangkan untuk pelaku usaha perseorangan akan dikenakan tarif pajak 
progresif sesuai ketentuan Undang-undang PPh pasal 17 dengan PTKP sebagai pengurang penghasilan. Sedangkan pada peraturan perpajakan yang baru, yaitu pada PP no 46 tahun 2013 yang mengatur pajak penghasilan bagi wajib pajak yang memiliki peredaran bruto tidak lebih dari $\mathrm{Rp} 4,8 \mathrm{M}$ ditentukan bahwa tarif pajak final $1 \%$ dari penghasilan bruto.

\section{METODE PENELITIAN}

\section{Jenis Penelitian}

Penelitian ini menggunakan penelitian kualitatif deskriptif. Penelitian kualitatif merupakan penelitian yang termasuk serangkaian teknik interpretatif yang berusaha untuk menggambarkan, memecahkan, dan menerjemahkan fenomena yang terjadi di dunia sosial dan penelitian ini bertujuan untuk mencapai pemahaman yang mendalam tentang suatu situasi (Cooper dan Schindler, 2014). Sedangkan penelitian deskriptif merupakan penelitian yang menjelaskan dengan memberikan uraian yang terstruktur mengenai keadaan, permasalahan, kejadian, serta menyediakan informasi.

\section{Populasi dan Sampel}

Populasi penelitian ini adalah UMKM yang berada di Daerah Istimewa Yogyakarta. Penentuan sampel dalam penelitian ini menggunakan metode purposive sampling yaitu penentuan sampel dengan menggunakan kriteria tertentu. Adapun kriteria yang digunakan adalah sebagai berikut.

a. Responden merupakan wajib pajak orang pribadi atau badan tidak termasuk bentuk usaha tetap.

b. Memiliki peredaran bruto kurang dari Rp4.800.000.000 setahun.

c. Bukan merupakan Wajib Pajak Orang Pribadi yang melakukan kegiatan usaha perdagangan dan/atau jasa yang dalam usahanya menggunakan sarana atau prasarana yang dapat dibongkar pasang dan menggnakan sebagian atau seluruh tempat untuk kepentingan umum yang tidak berkepentingan bagi tempat usaha atau berjualan.

Setelah dilakukan pemilihan berdasarkan kriteria dipilihlah sampel berjumlah 8 UMKM di DI Yogyakarta. Hal ini disebabkan tidak diperlukannya jumlah sampel yang besar karena penelitian ini menggunakan penelitian kualitiatif yang tidak memerlukan jumlah informan yang banyak.
Menurut Chopper dan Schlinder (2014), salah satu ciri penelitian kualitatif adalah ukuran sampelnya yang kecil. Selain itu, Fersiani dan Riduwan (2015) menjelaskan apabila jumlah informan yang dibutuhkan terlalu banyak maka hasilnya menjadi tidak fokus. Dalam hal ini, keterbatasan tenaga, waktu, dan biaya menjadi pertimbangan lain yang diambil oleh peneliti.

Krippendorff (1991) menjelaskan bahwa ukuran sampel yang terdiri dari satu sampel sudah mencukupi apabila semua unit sampling benarbenar identik. Namun dalam penelitian ini peneliti melakukan wawancara dengan 5 pelaku UMKM untuk memperoleh data dan informasi yang mampu mewakili populasi.

Dengan demikian, daftar sampel penelitian ini adalah sebagai berikut.

\section{Tabel 2. Daftar Sampel Penelitian}

\begin{tabular}{cll}
\hline No & Nama UMKM & Bidang UMKM \\
\hline 1 & CV XXX & Industri manufaktur \\
2 & CV YYY & Industri manufaktur \\
3 & CV A & Perdagangan furniture \\
4 & CV A & Bakery \\
5 & WPOP 1 & Toko kelontong \\
6 & WPOP 2 & Catering \\
7 & WPOP 3 & Laundry \\
8 & WPOP & Kuliner \\
\hline
\end{tabular}

Sumber: Data diolah (2018)

Keterangan: Nama UMKM disingkat atas kemauan responden untuk dirahasiakan.

\section{Teknik Pengumpulan Data}

Penelitian ini menggunakan beberapa teknik yaitu:

a. Wawancara

Dalam hal ini, peneliti melakukan wawancara terhadap pemilik UMKM atau bagian akuntansi. Wawancara yang dilakukan adalah wawancara terstruktur.

b. Dokumentasi

Dalam hal ini, peneliti memperoleh data dokumen berupa pencatatan keuangan atau laporan laba rugi UMKM.

c. Observasi

Dalam hal ini, peneliti melakukan observasi atau pengamatan pada UMKM yang dijadikan sampel. 


\section{Metode Analisis Data}

Metode analisa deskriptif yang digunakan dalam penelitian ini adalah sebagai berikut.

a. Menerjemahkan hasil wawancara responden.

b. Menghitung beban pajak penghasilan responden dengan menggunakan perbandingan tarsif PP no 46 tahun 2013 dan UU no 36 Tahun 2008.

c. Menganalisis hasil perhitungan dan membandingkannya dengan teori keadilan dan asas atau syarat pemungutan pajak.

d. Memberikan kesimpulan dan saran.

\section{HASIL DAN PEMBAHASAN}

\section{Perhitungan Pajak Penghasilan Wajib Pajak Badan}

Responden penelitian ini yang termasuk Wajib Pajak Badan adalah sejumlah empat respon. Tabel 3 berikut akan meunjukkan perbandingan perhitungan pajak terutang dengan menggunakan UU No 36 Tahun 2008 dan PP No 46 Tahun 2013. Berdasarkan tabel 3, dapat dilihat bahwa CV XXX dengan margin laba sebesar 46,66\% menunjukkan apabila menggunakan UU No 36 Tahun 2008 jumlah pajak terutang adalah sebesar Rp 90.420.000 sedangkan apabila menggunakan PP No 46 jumlah pajak terutangnya adalah sebesar Rp 23.291.577. Artinya, CV XXX membayar pajak lebih rendah jika menggunakan PP No 46 Tahun 2013 dibandingkan dengan menggunakan UU No 36 Tahun 2008, yaitu selisih Rp 67.128.423. Dengan demikian, dapat disimpulkan bahwa PP No 46 menguntungkan bagi CV XXX. Pada CV YYY dengan margin laba sebesar 23,74\% menunjukkan bahwa selisih pajak terutang antara UU36/2008 dan PP 46/2013 adalah sebesar Rp 13.984.793 lebih hemat menggunakan PP 46/2013. Berbeda halnya, pada CV A dengan margin laba 8,02\% mengindikasikan antara UU 36/2008 dan PP 46/2013 memiliki jumlah pajak terutang yang sama. Sedangkan pada CV B dengan margin laba sebesar 5\% menunjukkan bahwa menggunakan PP 46/2013 justru membayar pajak lebih tinggi dibandingkan dengan menggunakan UU 36/2008. Pengenaan pajak dengan menggunakan PP 46 menjadi relatif lebih besar. Artinya, UMKM harus membayar pajak ke negara lebih besar dibandingkan apabila menggunakan aturan PP 46 Tahun 2013. Dengan demikian, dapat disimpulkan bahwa UMKM berupa Wajib Pajak Badan akan diuntungkan apabila margin yang diperoleh lebih dari 8\% (titik impas), sedangkan apabila margin yang diperoleh kurang dari $8 \%$ akan dirugikan. Hal ini sesuai dengan penelitian Prabantari dan Ardiyanto (2017) yang menjelaskan bahwa semakin lebih tinggi margin laba dari titik impasnya (8\%) maka beban pajak penghasilannya akan semaki menurun dan sebaliknya, apabila margin laba semakin lebih rendah dari titik impasnya maka beban pajak penghasilan akan semakin tinggi.

\section{Perhitungan Pajak Penghasilan Wajib Pajak Orang Pribadi}

Responden penelitian ini yang termasuk Wajib Pajak Orang Pribadi adalah sejumlah empat responden. Tabel 4 berikut akan meunjukkan perbandingan perhitungan pajak terutang dengan menggunakan UU No 36 Tahun 2008 dan PP No 46 Tahun 2013. Berdasarkan tabel 4 di atas, untuk perhitungan pajak WPOP apabila menggunakan tarif UU 36/2008 memperhitungkan PTKP dan menggunakan tarif pasal 17, sedangkan apabila menggunakan tarif PP 46/2013 langsung menggunakan tarif 1\% dikalikan dengan peredaran bruto. Dengan demikian, dapat dilihat bahwa WPOP 1 yang memiliki margin laba 25\% dan PTKP sebesar Rp 67.500.000,- lebih hemat jumlah pajak terhutangnya jika menggunakan PP 46/2013. Sedangkan pada WPOP 2 dengan margin laba 18\% dan PTKP sebesar Rp 72.000.000,menunjukkan bahwa menggunakan PP 46/2013 lebih tinggi pajak terutangnya. Artinya, dalam menghitung $\mathrm{PPh}$ terutang WPOP tidak hanya memperhatikan margin laba namun juga memperhitungkan PTKP wajib pajak tersebut. Selanjutnya, pada WPOP 3 dan WPOP 4 dengan tingkat margin laba sebesar $10 \%$ dan $7 \%$ dan dengan jumlah PTKP sebesar Rp 54.000.000 dan Rp 58.500.000 menunjukkan bahwa dengan menggunakan UU 36/2008, WPOP tidak perlu membayar pajak karena jumlah penghasilan kena pajak di bawah PTKP, sedangkan apabila menggunakan PP 46/2013 WPOP 3 dan WPOP 4 justru harus membayar pajak dalam jumlah yang cukup besar yakni Rp 4.848.506 dan Rp 6.973.280.

\section{HASIL DAN PEMBAHASAN}

Keadilan dalam Penerapan PP 46 Tahun 2013 pada Perhitungan Pajak Penghasilan Wajib Pajak Badan

Pengenaan Pajak Penghasilan Terutang sebelum diberlakukan PP No 46 bagi Wajib Pajak Badan yang memiliki peredaran bruto di bawah $\mathrm{Rp}$ 
Tabel 3. Perhitungan PPh Badan Menurut UU No 36/2008 dan PP No 46 Tahun 2013

\begin{tabular}{lcccc}
\hline Keterangan & CV XXX & CV YYY & CV A & CV B \\
\hline Peredaran Bruto (PB) & 2.329 .157 .700 & 1.598 .262 .000 & 598.454 .500 & 372.985 .000 \\
Harga Pokok Produksi & 1.242 .359 .700 & 1.218 .792 .000 & 550.458 .449 & 354.335 .750 \\
Laba Kotor & 1.086 .798 .000 & 379.470 .000 & 47.996 .051 & 18.649 .250 \\
Margin & $46,66 \%$ & $23,74 \%$ & $8,02 \%$ & $5,00 \%$ \\
Penghasilan Kena Pajak (PKP) & 723.360 .000 & 239.739 .300 & 47.876 .360 & 14.919 .400 \\
PPh Terutang tarif 50\% x 25\%x PKP(UU 36/2008) & 90.420 .000 & 29.967 .413 & 5.984 .545 & 1.864 .925 \\
PPh Terutang tarif 1\% x PB(PP No 46 Tahun 2013) & 23.291 .577 & 15.982 .620 & 5.984 .545 & 3.729 .850 \\
\hline
\end{tabular}

Sumber: Data diolah (2018)

Tabel 4. Perhitungan PPh WPOP Menurut UU No 36/2008 dan PP No 46 Tahun 2013

\begin{tabular}{lcccc}
\hline Keterangan & WPOP 1 (K/2) & WPOP 2 (K/3) & WPOP 3 (TK/0) & WPOP 4 (K/ 0) \\
\hline Peredaran Bruto & 1.569 .138 .000 & 871.375 .000 & 484.850 .600 & 697.328 .000 \\
Laba Bersih Kena Pajak & 392.284 .500 & 156.847 .500 & 48.485 .060 & 48.812 .960 \\
PTKP & 67.500 .000 & 72.000 .000 & 54.000 .000 & 58.500 .000 \\
Penghasilan Kena Pajak & 324.784 .500 & 84.847 .500 & $(5.514 .940)$ & $(9.687 .040)$ \\
PPh Terutang Progresif & & & & \\
5\% x (s/d 50jt) & 2.500 .000 & 2.500 .000 & & \\
15\% x (>50jt - 250jt) & 30.000 .000 & 5.227 .125 & & \\
25\% x (>250jt - 500jt) & 18.696 .125 & & & \\
30\% x (>500jt) & & & & \\
Jumlah PPh tarif umum (UU No 36/2008) & 51.196 .125 & 7.727 .125 & & - \\
PPh Terutang tarif 1\% (PP No 46 Tahun 2013) & 15.691 .380 & 8.713 .750 & 4.848 .506 & \\
\hline
\end{tabular}

Sumber: Data diolah (2018)

4,8M adalah dengan menggunakan pasal $31 \mathrm{E} \mathrm{UU}$ No 36 Tahun 2008 yaitu dengan tarif 50\% x 25\% atau tarif $12,5 \%$ dikalikan dengan penghasilan kena pajak. Namun sejak diberlakukan PP No 46 tahun 2013 bagi WP yang memiliki peredaran bruto kurang dari Rp 4,8M adalah sebesar 1\% dikalikan dengan peredaran bruto. Hasil penelitian ini menunjukkan bahwa dengan menggunakan tarif PP No 46 Tahun 2013 akan menguntukan bagi wajib pajak badan yang memiliki margin laba lebih dari titik impas yaitu $8 \%$. Apabila wajib badan memiliki margin laba kurang dari 8\% maka wajib pajak cenderung dirugikan dengan adanya PP 46/2013 ini. Hal ini dikarenakan dasar pengenaan pajak PP 46/2013 ini adalah peredaran brutonya bukan labanya. Artinya peraturan ini tidak memandang apakah perusahaan laba atau rugi. Pada UU 36/2008, wajib pajak badan baru dikenakan pajak apabila perusahaan memperoleh laba. Namun pada PP 46/2013, apabila perusahaan mengalami kerugian maka akan tetap dikenakan pajak karena dasar pengenaannya adalah peredaran brutonya.
Hasil penelitian ini membuktikan bahwa konsep keadilan dalam penerapan PP 46/2013 belum tercermin. Hal ini dibuktikan dengan wajib pajak dengan margin laba tinggi justru lebih rendah membayar pajak lebih rendah jika dibandingkan dengan aturan sebelumnnya. Sedangkan wajib pajak yang memiliki margin laba rendah justru membayar pajak lebih tinggi. Selain itu, peraturan ini juga tidak memperhatikan kondisi perusahaan yakni mengalami laba atau rugi. Bahkan jika perusahaan mengalami kerugian akan tetap dikenakan untuk membayar pajak. Hal ini dikarenakan dasar perhitungannya adalah peredaran bruto bukan laba perusahaan.

Penelitian ini sesuai dengan Aditra, Kertahadi, dan Handayai (2016) serta Prabantari dan Ardiyanto (2017) yang mengungkapkan bahwa PP ini tidak sesuai dengan konsep keadilan. Dalam konsep keadilan seharusnya pemungutan pajak harus dilaksanakan dengan memperhatikan kemampuan masing-masing wajib pajak. Namun dalam kenyataannya, UMKM yang berbentuk badan yang memiliki tingkat 
keuntungan (margin laba) kecil justru membayar pajak yang lebih tinggi. Sebaliknya UMKM yang berbentuk badan yang memiliki tingkat keuntungan besar justru hemat dalam membayar pajak dengan menggunakan PP ini. Hal ini tentu saja bertolak belakang dengan konsep keadilan.

\section{Keadilan dalam Penerapan PP No 46 Tahun 2013 pada Perhitungan Pajak Penghasilan Wajib Pajak Orang Pribadi}

Dalam perhitungan Pajak Penghasilan Terutang sebelum diberlakukan PP No 46 bagi Wajib Pajak Badan yang memiliki peredaran bruto di bawah Rp 4,8M adalah dengan meghitung laba bersih sebelum pajak dikurangi dengan penghasilan tidak kena pajak (PTKP), baru kemudian dikalikan dengan tarif progresif pasal 17. Namun sejak diberlakukan PP No 46 tahun 2013 bagi WP yang memiliki peredaran bruto kurang dari Rp 4,8M adalah sebesar 1\% dikalikan dengan peredaran bruto. Hasil penelitian ini menunjukkan bahwa dengan menggunakan tarif PP No 46 Tahun 2013 pemungutan PPh pada pelaku UMKM perseorangan akan menguntungkan jika UMKM tersebut memiliki profit margin laba $25 \%$ $(>20 \%)$, namun akan merugikan jika margin laba kurang dari 20\%. Peraturan ini tidak memperhatikan laba atau rugi karena jumlah pajak terutang hanya dihitung berdasarkan penghasilan bruto saja. Artinya peraturan ini tidak memandang apakah wajib pajak tersebut mengalami laba atau rugi. Bahkan tidak memperhatikan jumlah yang ditanggung oleh wajib pajak atau PTKP.

Hasil penelitian ini membuktikan bahwa konsep keadilan dalam penerapan PP 46/2013 belum tercermin. Konsep keadilan menurut perpajakan adalah bukan hanya memperhatikan besaran pajak antara seseorang yang berpenghasilan yang sama besar akan dikenakan pajak yang sama, namun juga harus memperhatikan jumlah tanggungannya. Dalam hal ini, belum tercermin dalam PP ini.

\section{Pro Kontra Penerapan PP No 46 Tahun 2013}

Dalam penerapannya, PP 46 tahun 2013 ini menimbulkan pro dan kontra. Berdasarkan hasil wawancara yang telah dilakukan pihak yang pro terhadap peraturan ini adalah pelaku UMKM dalam bentuk badan kategori menengah yang memiliki margin laba di atas $8 \%$. Hal ini dikarenakan menguntungkan bagi mereka karena lebih hemat membayar pajak juga dikarenakan PP ini lebih memudahkan mereka dalam menghitung pajak terutangnya.

Perhitungan PP ini lebih sederhana, yakni hanya mengalikan tarif $1 \%$ dengan peredaran bruto. Artinya, pelaku UMKM tidak perlu melakukan rekonsiliasi fiskal untuk menentukan laba secara fiskal. Hal ini sesuai dengan hasil wawancara peneliti terhadap pelaku UMKM bahwa mereka mengaku dengan adanya PP ini, mereka tidak perlu menghitung pajak yang rumit. Hal ini dikarenakan beberapa pelaku UMKM belum memahami sepenuhnya tentang pembuatan laporan laba rugi fiskal, akibatnya mereka menggunakan jasa akuntan/ konsultan untuk menghitung pajak terutangnya. Hal ini tentu saja menambah biaya bagi mereka. Bahkan ada salah satu UMKM yang enggan melakukan pembayaran pajak karena terlalu susah memahami menghitung pajak.

Selain itu, jika dilihat dari syarat yuridis. PP ini telah memenuhi syarat tersebut. Hal ini ditunjukkan dengan dalam pemungutannya, telah sesuai dengan peraturan yang berlaku yaitu PP No 46 Tahun 2013 dan jika dilihat dari asas kepastian (certainty), Peraturan ini juga memiliki kepastian yakni tarifnya adalah $1 \%$ dari peredaran bruto.

Kemudian jika dilihat dari asas kenyamanan (convenience), PP ini juga telah memenuhi asas tersebut. Pasalnya, PP ini mengatur bahwa pajak dibayar setiap bulan sesuai dengan omset yang diperoleh. Hal ini bertujuan agar wajib pajak tidak harus menghimpun dana dalam jumlah yang besar dan cenderung memberatkan pada akhir tahun (Aditra, Kertahadi, dan Handayani, 2015). Hal ini juga sesuai konsep asas pemungutan pajak Adam Smith dalam Waluyo (2013) yang mengungkapkan bahwa pembayaran pajak sebaiknya memperhatikan waktu yang tidak menyulitkan wajib pajak dalam membayar.

Apabila dilihat dari syarat finansial, PP ini juga telah memenuhi. Syarat finansial merupakan syarat yang mengharuskan bahwa dalam pemungutan pajak hendaknya dilakukan dengan efisien. Hal ini ditunjukkan dengan metode perhitungan pajak terutang sejak awal, yakni 1\% dikalikan dengan peredaran bruto. Hal ini memberikan pemahaman dan kemudahan dalam hal perhitungan pajak karena tidak perlu untuk menghitung laba atau rugi bahkan tidak perlu melakukan rekonsiliasi fiskal. Artinya PP 
ini dapat menekan biaya seperti biaya jasa konsultan pajak atau biaya jasa akuntan untuk membuat pembukuan fiskal.

Sebaliknya, pihak yang kontra terhadap aturan ini adalah pelaku UMKM kategori mikro, kecil, dan menengah yang memiliki margin laba di bawah $8 \%$ atau UMKM yang masih perseorangan (WPOP). Hal ini dikarenakan pajak terutang mereka menjadi lebih besar. Hal ini sesuai dengan penelitian Anita (2015) yang menjelaskan bahwa dalam pelaksanaannya, PP ini menuai berbagai persepsi negatif di masyarakat karena peraturan ini hanya akan dianggap menambah beban masyarakat terutama para pelaku UMKM di Indonesia.

Dengan adanya PP ini sebenarnya merupakan salah satu langkah bagus pemerintah karena diharapkan dengan adanya peraturan ini dapat menumbuhka kesadaran bagi masyarakat atau pelaku UMKM khususnya untuk membayar pajak sehingga dapat meningkatkan penerimaan pajak bagi negara. Apalagi jika melihat besarnya potensi UMKM, diharapkan akan dapat berkontribusi untuk menyumbang penerimaan negara pada sektor pajak. Sebaliknya, pemerintah juga diharapkan lebih memperhatikan dan memberikan sumbangan bagi kemajuan UMKM.

\section{KESIMPULAN}

Berdasarkan pembahasan yang telah dijabarkan sebelumnya, kesimpulan penelitian ini adalah sebagai berikut.

1) Dalam penerapannya pada UMKM badan, $P P$ 46 tahun 2013 tidak memperhatikan konsep keadilan. Hal ini ditunjukkan dengan hanya UMKM yang memiliki profit margin di atas $8 \%$ yang diuntungkan sedangkan UMKM yang profit marginnya kurang dari $8 \%$ akan mengalami kerugian jika menerapkan PP ini.

2) PP 46 tahun 2013 tidak memperhatikan pelaku UMKM mengalami laba atau rugi. Bahkan dalam hal pelaku UMKM mengalami kerugian tetap dikenakan pajak karena perhitungan pajak didasarkan pada peredaran bruto.

3) Dalam penerapannya pada UMKM perseorangan, PP No 46 Tahun 2013 juga tidak memperhatikan konsep keadilan karena tidak memperhatikan jumlah tanggungannya atau PTKP.

4) PP 46 Tahun 2013 juga memberikan manfaat seperti kemudahan dan kesederhaan dalam menghitung, menyetor, dan melaporkan pajak, serta bagi pemerintah adalah adanya peningkatan jumlah wajib pajak dan peningkatan penerimaan pajak yang diterima oleh negara. Selain itu juga telah memenuhi asas-asas pemungutan pajak seperti yuridis, finansial, dan kenyamanan.

Saran untuk penelitian ini adalah sebagai berikut.

1) Pengenaan pajak UMKM sebaiknya didasarkan pada penghasilan neto bukan pada peredaran bruto.

2) Penurunan tarif. Bagi beberapa UMKM yang memiliki peredaran bruto tinggi, jumlah $1 \%$ tergolong mudah bagi mereka. Namun bagi UMKM yang mikro dan kecil jumlah ini dirasa masih sangat tinggi. Mengingat margin laba bagi usaha kategori mikro dan kecil rendah.

3) Adanya dukungan dan perhatian Pemerintah terhadap UMKM untuk mendorong kemajuan UMKM.

\section{DAFTAR PUSTAKA}

Aditra, Al Hakim, Kertahadi, dan Siti Ragil Handayani. (2016). Implementasi Peraturan Pemerintah No 46 Tahun 2013 tentang Pajak Penghasilan Final Usaha Mikro Kecil Menengah (Kota Surabaya). Jurnal Perpajakan (Jejak), Vol 10 No 1 Tahun 2016, perpajakan.studentjournal. ub.ac.id.

Anita, Tri. (2015). Analisis Penerapan PP 46 Tahun 2013 bagi UMKM dalam Mempertahankan Keberadaan UMKM di Indonesia. Sosio E-Kons, Vol 7 No 3 Desember 2015, halaman 266-271.

Cooper, Donald R. dan Pamela S. Schindler. (2014). Business Research Methods. New York: Mc Graw Hill.

Diatmika, I Putu Gede. (2013). Penerapan Akuntansi Pajak atas PP No 46 Tahun 2013 tentang PPh atas Penghasilan dari Usaha Wajib Pajak yang Memiliki Peredaran Bruto tertentu. Jurnal Akuntansi Profesi, Vol 3 No 2 Desember 2013.

Fersiani, Ekawati dan Akhmad Riduwan. (2015). Respons Pelaku UMKM atas Peraturan Pemerintah Nomor 46 tahun 2013. Jurnal Ilmu dan Riset Akuntansi. Vol 4 No 12 Tahun 2015. 
Kementrian Keuangan. (2016). http://www.anggaran. depkeu.go.id/content/publikasi/2016\%20 BIB\%202017.pdf diakses tanggal 19 Maret 2018 pukul 11.30

(2016). https://www.kemenkeu.go.id/ sites/default/files/bibfinal.pdf diakses tanggal 19 Maret 2018 pukul 11.50 WIB.

Krippendorrf. (1996). Pengantar Metodologi Riset Sosial. Bandung: CV Mandar Maju.

Mardiasmo. (2016). Perpajakan Edisi Revisi 2016. Yogyakarta: Penerbit Andi.

Pemerintah Republik Indonesia. (2008). UndangUndang No. 7 Tahun 1983 tentang Pajak Penghasilan Sebagaimana telah Beberapa Kali Diubah Terakhir dengan Undang-Undang Republik Indonesia Nomor 36 Tahun 2008.
(2008). Undang-Undang No. 20 Tahun 2008 tentang Usaha Mikro Kecil dan Menengah.

(2013). Peraturan Pemerintah Nomor 46 Tahun 2013 tentang Penghasilan atas Penghasilan dari Usaha yang Diterima atau Diperoleh oleh Wajib Pajak yang Memiliki Peredaran Bruto Tertentu.

Prabantari, Faizara dan Moh didik Ardiyanto. (2017). Implementasi Pajak Penghasilan Berdasarkan Peraturan Pemerintah Nomor 46 Tahun 2013 (Studi pada UMKM di Jawa Tengah dan Daerah Istimewa Yogyakarta). Diponegoro Journal of Accounting, Vol 6 Nomor 4 Tahun 2017 halaman 1-12, ISSN (online): 2337-3806.

Resmi, Siti. (2016). Perpajakan Teori dan Kasus. Jakarta: Salemba Empat. 